\title{
Medical teaching professionalization: quality of training
}

\author{
Claribel Plain Pazos ${ }^{1 *}$, Odalis Ruíz Pérez ${ }^{2}$, Isabel Julia Veitía Orrieta ${ }^{2}$, Carmen Rosa Carmona Pentón ${ }^{1}$, Elsa Núñez Escobar ${ }^{3}$, Anisbel Pérez \\ de Alejo Plain ${ }^{4}$ \\ ${ }^{1}$ Specialist of II Degree in Comprehensive General Medicine, Assistant Professor, Faculty of Medical Sciences of Sagua la Grande, Villa Clara, \\ Cuba. \\ ${ }^{2}$ Doctora en Ciencias pedagógicas, Profesor Titular, Universidad Central "Marta Abreu" de Las Villas. Cuba. \\ ${ }^{3}$ Specialist of I Degree in Comprehensive General Medicine, Assistant Professor, Faculty of Medical Sciences of Sagua la Grande, Villa Clara, Cuba \\ ${ }^{4} 3$ rdYear Student of Medicine, Medical Faculty of Medical Sciences of Sagua la Grande, Villa Clara, Cuba. \\ *Corresponding Author: Claribel Plain Pazos, Specialist of II Degree in Comprehensive General Medicine, Assistant Professor, Faculty of \\ Medical Sciences of Sagua la Grande, Villa Clara, Cuba.
}

Received date: April 14, 2021; Accepted date: June 04, 2021; Published date: June 09,2021

Citation: Claribel P Pazos, CRC Pentón, AP Alejo Plain, Yiset M Pedraja, LIS Martínez. (2021) Contraception in Adolescence: Social Necessity. Biomedical Research and Clinical Reviews. 4(1); DOI: 10.31579/2692-9406/062

Copyright: (c) 2021 Claribel Plain Pazos, This is an open-access article distributed under the terms of the Creative Commons Attribution License, which permits unrestricted use, distribution, and reproduction in any medium, provided the original author and source are credited.

University teaching professionalization is a necessity in modern society. The scientific and technical revolution that has been taking place in the world demands a different preparation for teachers. Modern universities need professors adapted to these new times. The professionalization of teachers today constitutes a challenge as well as a social commitment.

The professionalization of the university faculty has characteristics that mark its particularity in correspondence with the corporate purpose of the organization and is valued as one of the essential pillars to meet social demands and demands. In this way, it constitutes a necessity, as a condition for the certification of the quality of the processes that are developed in it [1].

Currently the National Public Health System in Cuba has been immersed in a process of transformation with a view to increasing the main health indicators with efficiency, rationality and maintaining sustainable development [2]. To achieve this it is necessary to draw up actions that involve human resources from their training process.

In recent years, a growing concern has been manifested, both nationally and internationally, for the pedagogical preparation of teachers of Higher Medical Education [3]. The teacher of these times must have pedagogical mastery in such a way that he is capable of transmitting his knowledge and these are assimilated by his students.

In this context, the professionalization of the university professor is a priority, a process that should be understood as a continuous and systematic improvement of their academic qualification, which is in no way spontaneous or totally self-directed, since it requires the existence of institutional strategies that stimulate and guide said process, in addition to the individual interest of each teacher involved [2]. The teacher must be the first manager of his own knowledge.

The assumption that the doctor, because of his quality, is qualified to teach, and therefore, that the students learn from him, is part of the past. The challenge is to go further; It is imperative to have the implementation of properly structured programs, based on the assessment of needs within each school and a study of their impact [4,5]. It is essential that the teacher of the medical career, in addition to the knowledge of his profession, has the ability to elucidate the context where he is transmitting his knowledge.
Studies carried out by various authors indicate that there is no identity of the doctor as a teacher, so the issue of teacher professionalization is relevant and is a guideline for discussion in research. Not knowing the pedagogical aspects that the teaching profession entails, doctors look for elements such as roles, profiles and identity as a way to approach the subject. Likewise, in the research on the roles of the medical teacher, the lack of an identity towards the educational field is reaffirmed. This shows that there is a need to professionalize teaching in the medical area since when the doctor teaches in front of the students he does not stop acting as such, that is, he acts as a doctor and not as a teacher [6].

In research carried out with medical professors, it has been found that teaching is considered a secondary activity to the medical profession and that the teaching career is not considered a profession [5, 7]. However, the medical teacher, as a component of the teaching-learning process, becomes a basic piece and his participation acquires an active and significant quality as a facilitator of learning, helping at all times to the comprehensive training of the student $[4,5]$. To be a professor at a medical school, it is not enough to be a good health professional, but you must achieve the skills for teaching professionalization.

Hence, it is appropriate to reflect on what the role of the medical teacher who trains other doctors is and should be and what strategies the responsible and adequately pedagogical exercise of their work in the classroom and in practice settings presents [8]. Together with this, he must incorporate to his knowledge all the available resources of the new technologies that allow him to interact with the student efficiently.

Cuban medical education has been linked since 1959 to the development of the National Health System (SNS), and since the Declaration of AlmaAta, it has benefited from the conception of primary care and family medicine. Therefore, the formation of human capital corresponds to the needs of the SNS [9]. The medical university builds its own human resources and guarantees you a job after completing your undergraduate studies.

The Ministry of Higher Education has established three main teaching categories in Cuba: assistant professor, assistant professor and tenured professor. There is also the transitory category of instructor, which are 
established in Ministerial Resolution Number 85/2016 [5, 10]: "Regulation for the Application of the Teaching Categories of Higher Education". It is essential for the transit through these categories to maintain a satisfactory job as a teacher, as well as to demonstrate knowledge about foreign language and social problems of science, in addition to being active in research, development and technological innovation. 5 Teachers who do not meet these requirements cannot move to a higher teaching category and may even lose the one they hold.

If we talk about the doctor's teaching training, this implies that the doctor assumes himself with this duality of profession: as a doctor and as a teacher, and acquires responsibility for his training path in teaching. Depending on the meaning that teachers have regarding teaching, it is the way they act day by day in their teaching practice. Therefore, the meaning that the doctor as a teacher gives to teaching is an important element to consider in the study of their training processes.

It is necessary to study how the postgraduate processes contribute to the pedagogical preparation of the trainers, so that the practice is reflected, supported and guided by a theory that consistently addresses this important issue [3]. In order to be a good teacher, the doctor must master the pedagogical tools, in addition to the content of his profession, to ensure that his students learn and obtain quality training.

\section{References}

1. Rojas Valladares AL, Soria León G. (2016) Reflexiones acerca de la profesionalización docente en función de la calidad de los procesos universitarios, en la Universidad Metropolitana del Ecuador. Universidad y Sociedad 8(2).

2. VerdeciaEA. (2018) Retos de la educación en las ciencias médicas de Mayabeque. Medimay. 25(3):178-181.
3. Enríquez Clavero J.O González Hernández. (2019): "La superación profesional pedagógica de los docentes en la educación médica superior cubana", Revista Atlante: Cuadernos de Educación y Desarrollo (abril 2019). 2019.

4. Osornio Castillo L, Sánchez Reyes C, Ríos Saldaña MR, Méndez Cruz AR, Moreno Fernández AA, Ángeles Cruz RT, Hurtado Díaz JL. (2015) Autoevaluación de los profesores de clínica integral de medicina sobre su desempeño docente. RevInvest en EducMéd 4(16): 183-189.

5. Plain Pazos C, Carmona Pentón CR, Núñez Escobar E, Pérez de Alejo Plain A, Alfonso García L, Caraballo Moya N, Martínez Chávez Y. (2020) TeachingProfessionalization of theCurrentNeedPhysician. Arch of Emerg Med and Int Care. 5(6): 1-3.

6. Pastro Fiat SM. (2015) Saberes docentes en educación médica. Journal for Educators, Teachers and Trainers. 6(1):124-144.

7. Campos Costa NMS. (2010) La formación pedagógica de profesores de medicina. Rev. Latino-Am. Enfermagem. 19(1): 1-7.

8. Jara Gutierrez NP, Díaz López MM, Zapata Castañeda PN. (2015) Desafíos educativos para el profesor de medicina: evaluación de su desempeño. IATREIA 28(3): 292-299.

9. Vela Valdés J, Salas Perea RS, Quintana Galende ML, Pujals Victoria N, González Pérez J, Díaz Hernández L, et al. (2018) Formación del capital humano para la salud en Cuba. RevPanam Salud Publica.

10. Cuba, Ministerio de Educación Superior. (2017) Resolución Ministerial No. 85/2016 del 17 de octubre del 2016. Reglamento para la aplicación de las categorías docentes de la educación superior. Gac Of Repub Cuba5.

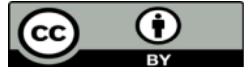

This work is licensed under Creative Commons Attribution 4.0 License

To Submit Your Article Click Here: Submit Manuscript

DOI: $10.31579 / 2692-9406 / 062$
Ready to submit your research? Choose Auctores and benefit from:

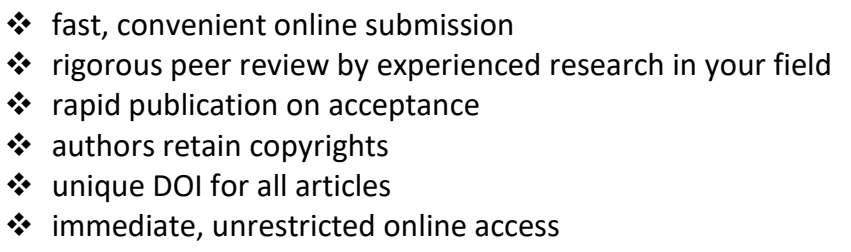

At Auctores, research is always in progress.

Learn more www.auctoresonline.org/journals/biomedical-research-andclinical-reviews- 